accuracy by means of the alignment of points on scale-carrying lines. For the remainder of April 21, a programme of excursions and entertainment was provided.

The morning of April 22 was occupied with two lectures: Dr. W. M. Hampton outlined the mathematical investigations which have been made into certain practical problems in glass-working, showing a very fair correspondence between theory and practice. Prof. R. Peierls, of the University of Birmingham, spoke on "Mathematics-Dead or Alive?", and emphasized a principle which has always been fundamental in the Association's policy, that mathematics cannot successfully be taught as a dead subject, but only as a living organism in contact with present-day developments, whether these be in the applications of mathematics to problems of importance in other sciences or in the extension of mathematical knowledge itself by current research.

Two valuable discussions filled the afternoon session. In opening the discussion on "A Realistic View of Main School Geometry", Mr. C. V. Durell proclaimed that geometry is a physical science, not a pattern of logical relations between mathematical abstractions ; but Mr. Robson, following Mr. Durell, maintained that a logical system of some kind must be developed in the later years of the school geometry course. In the following open discussion, there appeared to be some feeling among the younger teachers that the reaction against Euclid in the schools may be in danger of going too far. The other discussion, on "Alternatives to School Certificate Mathematics, with reference to Secondary Modern Schools", opened by Mrs. E. M. Williams (City of Leicester Training College) and Mr. R. C. Lyness, a Ministry of Education inspector, reflected the Association's close attention to the problem of mathematical teaching in the new Modern School, where there is a danger that content and method may be too closely.a copy of content and method in the Grammar School, instead of being firmly based and developed on the functional needs of the Modern School.

In the evening, Mr. J. A. Petch, secretary of the Joint Matriculation Board, spoke on ta subject of vital interest to teachers, "Statistical Treatment of Examination Niarks". Mr. Petch described the mathematical methods used in dealing with largescale external examinations in order to minimize variations, to standardize the markings of a panel of examiners who share the assessment of scripts in one subject, and to set up a standard of compacison between markings in different subjects. His audience welcomed his demonstration of the skill, care and patience devoted to the assessment of the merits of the School Certificate candidate.

On the morning of April 23, a first step was made on a programme which the Association hopes to follow up in later meetings, by getting speakers from outside Great Britain to deal with aspects of mathematical education in their countries. On this occasion, Mr. B. T. Gilroy, of New South Wales, and Mr. R. G. Keats, of South Australia, outlined the system of mathematical teaching in the secondary schools and universities of Australia. Dr. H. C. Christofferson, of Oxford, Ohio, described the ideals which inspire the teachers of mathematics in the high schools of the United States ; members of the Association supported his plea for a complete fusion of theory with practice, appreciated his illustrations of detail, and relished his fund of American anecdote.

\section{A NEW FOSSIL GYMNOSPERMOUS 'OVARY' RPl'}

7 HE discovery of a new type of many-seeded fruit bogy fro $n$ the Lower Carboniferous of Scotland is a iftiter of more than local palæobotanical interest. Thel publication by Prof. John Walton of the ful description of Calathospermum scoticum (Tran .. Roy. Soc. Edin., 61, 719; 1949), which has bef afraited since the preliminary account in $1940^{1}$, is herefore most welcome, although it is difficult to withhold a protest that any learned society, so long after the end of the War, should subject important scientific work to the treatment recorded in the superscription "MS. received May 10th, 1947. Read May 3rd, 1948. Issued separately Feb. 11th, 1949."

Calathospermum scoticum consists of isolated fruit bodies of large size (up to $24 \mathrm{~mm}$. $\times 45 \mathrm{~mm}$.), shaped like a tulip and each consisting of a cupule divided into six segments which surround either a central mass of stalks or an equivalent number of stalked ovules. Compared with other known many-seeded cupules (Gnetopsis and Calathiops), Calathospermum is the first to be discovered of Palæozoic age in which the mode of arrangement of the ovules inside the cupule can be studied, thereby contributing some very interesting comparative facts to place beside the better known but much more recent Caytonia. The stalks in Calathospermum are partly borne on the margins of the cupule segments but also on a quadri. partite central column to which some twenty-four of them may be attached. Each stalk has a central vascular strand which is continued into the integument of the ovule and out into its appendages. The latter consist of nine terete apical projections of considerable length which terminate the orthotropous ovules. In the form of these appendages and in other characters the ovules themselves resemble very closely those of Salpingostoma dasi described by Gordon in $1941^{2}$, although they are thought to be specifically distinct. Salpingostoma, interestingly enough, is itself the oldest structurally preserved seed which can be assigned with certainty to the Pteridosperms.

In attempting to interpret the presence of two states of the fruit bodies, those containing ovules on badly preserved (and therefore perhaps immature) stalks and those containing well-preserved stalks but no ovules, the suggestion is made that the latter are probably in the more advanced developmental state. It is thought that, as the seeds ripened, their stalks may have elongated and extruded them from the cupule, after which they became detached. From details observed in the histology of the cupule seg. ments it is thought that these may have opened out in a perianth-like manner during extrusion of the seeds, although in the water-logged condition pre. ceding fossilization they had again closed.

The fruit body appears to have been borne on the end of a stalk containing a single crescentic vascular strand. It is therefore concluded that they were foliar and not axial appendages.

For the non-specialist reader a valuable com. mentary on these facts will be found in the recently published Symposium on the Evolution and Classification of the Gymnosperms held in Chicago in December 1947. Prof. H. N. Andrews's paper ${ }^{3}$ in particular supplies a very valuable background in his survey of existing knowledge of Pteridosperms ir general, while Prof. B. Sahni ${ }^{4}$, by giving details 0 
another new Gymnospermous group, the Jurassic Pentoxyleæ, in which naked seeds with fleshy integuments are clustered directly on to a cauline cone axis totally devoid of any trace of leaf-like appendages, provides a wholesome corrective against the hasty generalizations which Calathospermum by itself might arouse in the unwary. Both Calatho. spermum and the Pentoxyleæ are, however, of first-rate theoretical importance in the phylogeny of the Gymnosperms, and both, therefore, merit the attention of a general botanist.

${ }^{1}$ Walton, J., "Introduction to the Study of Fossil Plants" (London. 1940).

'Gordon, W. T., Trans. Roy. Soc. Edin., 60, 427 (1941).

'Andrews, H. N., Bot. Gaz., 110, 13 (1948).

'Sahni, B., Bot. Gaz., 110, 47 (1948).

1016

\section{EUROPEAN CORN BORER IN NORTH AMERICA}

$\mathrm{T}$ HE European Aprn breer (Pyrausta nubilalis) was first found in the United States in 1917, among swegt coln ndar Boston, Mass., where it was infegting affarea of at least 100 square miles. It was later aund that the insect was also present at the same time near St. Thomas, Ontario. The actual date or year of entry of this dangerous pest into North America is uncertain, but circumstantial evidence points to its occurrence among broom-corn imported from Hungary or Italy between 1909 and 1914.

The insect is among the most threatening of all pests of Indian corn (or maize) ; accumulated knowledge shows that its eradication is not possible, but various cultural practices can be adopted so that there results a reduction in the losses caused by the insect. According to W. A. Baker and W. G. Bradley, entomologists of the U.S. Bureau of Entomology and Plant Quarantine, the damage caused by the borer in the United States in 1945 was estimated at $36,700,000$ dollars. In a recent publication by these two entomologists* they state that infested areas extend all down the east coast and across the continent to districts west of the Great Lakes. The favourite plant host in America, as in Europe, is Indian corn (maize), but the insect also attacks beans, soybean, millet, oats, potatoes and some other cultivated crops. Garden flowers are also infested, notably dahlias, gladioli, zinnias, chrysanthemums and various weeds that grow among or bordering the maize crop. Among the Lakes States the corn borer is single-brooded and feeds almost entirely on maize, whereas in the southern and eastern parts of the infested region two or even three broods prevail, and the insects affect a wide range of different plants. The injuries it causes are effected during the larval stages when it tunnels into the stalk, main stem or mid-rib of its host-plant, as the case may be. As a result of the damage thus caused, much of the nutriment is cut off from the ear or flowering part, which weakens or flags and breaks.

As regards methods of controlling the borer, the indigenous insect parasites have proved of no avail. They number twenty-four different species, yet their combined activities have resulted in the destruction

* U.S. Department of Agriculture. Farmers' Bulletin No. 1548 : The European Corn Borer; its Present Status and Methods of Con trol. Revised edition, by W. A. Baker and W. G. Bradley. Pp. 46. (Washington, D.C.: Government Printing Office, 1948.) 15 cents. of only a fraction of 1 per cent of the borer. Large numbers of foreign parasites have been introduced from Europe and have established themselves, but it is premature to state whether they will prove to be effective controlling agents. At the present time the corn borer can be best controlled by utilizing or destroying all parts of infested plants before any of the insects they may contain are able to change into the adult or moth stage. Feeding affected crops to livestock either directly from the field or as silage is a valuable method. In other cases deep ploughing beneath the soil or complete burning of all infested vegetation before the spring when the moths appear is recommended. Any method that leaves behind living borer caterpillars among the plant residues merely provides for the infestation to go on during the following year. The use of insecticidal sprays containing D.D.T. or other toxic agents has been recommended for use during the period when the eggs are hatching, in order to destroy the young caterpillars.

\section{6 \\ FORTHCOMING EVENTS \\ (Meetings marked with an asterisk * are open to the public) \\ Monday, May 9 \\ RoYaI, GEOGRAPH aA, SOCIETY (at Kensington Gore, London, S.W.7), at $5 \mathrm{~mm}$. - cre S. W. Wooldridge and Mr. S. H. Beaver "Land Ise d d iculace Mineral Working in Pritain". UN URSIT
Colle "Aspects of Biological Discovery, 2, Circulation of the Blood"." \\ INSTTTUTION OF FIECTRICAL ENGINEERS, EDUCATION DISCUSSION CIRCLE (at Savoy Place, Victoria Embankment, London, W.C.2), a 6 p.m.-Discussion on "Graphical Methods in Teaching Electrica} Engineering (including Radio)" (to be opened by Mr. S. N. Ray).

\section{Tuesday, May 10}

RoYal ANTHRopological INSTituty (at 21 Bedford Square, ROYAL ANTHROPOLOGICAL INSTITUTK (at 21 Bedford Square, London, W.C.1), at 5 p.m.-.

UNIVERSITY OF LONDON (at the London School of Economics and Political Science, Houghton Street, Aldwych, London, W.C.2), a 5 p.m.- Prof. D. V. Glass : "The Application of Social Research" (Inaugural Lecture).*

Zoological SOCIETy OF LONDON (at the Zoological Gardens, Regent's Park, London, N.W.8), at 5 p.m.-Scientifte Papers.

SOCIETY OF ChEMICAL INDUSTRY, CheMICAL ENGINGERING GROUP (at the Geological Society, Burlington House, Piccadilly, London, W.1), at $5.30 \mathrm{p.m}$.-Mr. W. Barr and Mr. J. Frskine: "Tine Manufacture and Use of Stainless-Clad Steel".

UNIVERSITY OF LONDON (at the London School of Hygiene and Tropical Medicine, Keppel Street, London, W.C.1), at 5.30 p.m.Prof. Jacques Tréfouẻl (Paris): "Some Advances in Chemotherapeutic Research at the Pasteur Institute"."

ILLUMINATING ENGINERRING SocieTr (at the Royal Society of Arts, John Adam Strot, General Meeting; at 6.30 p.m.-An Address by Monsieur L. Gaymard.

Wednesday, May II

INSTITUTE OF FUel, NORTH-WESTRRN SECTION (at the Engineers' Club Albert Square, Manchester), at 11 a.m.-Conference on "Combined Heat and Power Supplies".

GEOLOGICAL SOCIETY OF LONDON (at Burlington House, Piccadilly, London, W.1), at 5 p.m.-Dr. Robert Broom, F.R.S.: "South Africa's Contribution to our Knowledge of Man's Evolution;"

UNIVRRSITIES FEDERATION FOR ANIMAL WRLFARE (in the Anatomy Theatre, University College, Gower Street, London, W.C.1), at 5.15 p.m.-Dr. Jean-Paul Harroy: "Nature Protection".

Institute of PeTroleum (at Manson House, 26 Portland Place. London, W.1), at 5.30 p.m.-Mr. F. Morton: "Examination of Crude Oils in relation to Geological Formations".

Physical Sochety, Low Temperature Group (in the Lecture Theatre, Science Museum, Exhibition Road, London, S.W.7), at 5.30 . - Discussion on "The Use of Thermodynamic Diagrams in Industry" (to be opened by Prof. D. M. Newitt, F.R.S.).

ROYAL Institution (at 21 Albemarle Street, London, W.1), at 9 p.m.-Prof. E. K. Rideal, F.R.S. : "How Crystals Grow".

Thursday, May 12

Council for the Preservation of Rural England (at the Royal Institute of British Architect3, 66 Portland Place, London, W.1), at 2.30 p.m. - Annual General Meeting.

RoYal Society (at Burlington House, Piccadilly, London, W.1) at 4.30 p.m.-Prof. H. Raistrick, F.R.S. : "A Region of Biosynthesis" (Bakerian Lecture) 